\title{
Hypoxic Preconditioning Decrease ROS and Increase SOD expression in Adipose-Derived Mesenchymal Cell
}

\author{
I Gde Rurus Suryawan ${ }^{1, *}$, Andrianto ${ }^{1}$, Ratna Dewi Cahyaningtias', Makhyan Jibril Al-Farabi ${ }^{1,2}$
}

I Gde Rurus Suryawan ${ }^{1, *}$, Andrianto', Ratna Dewi Cahyaningtias', Makhyan Jibril Al-Farabi ${ }^{1,2}$

'Department of Cardiology and Vascular Medicine, Soetomo General Hospital, Airlangga University, Mayjend. Prof. Dr. Moestopo Street No.6-8, Surabaya, INDONESIA.

${ }^{2} S$ chool of Health Management, University College London, Gower St, Bloomsbury, London WC1E 6BT, UK

\section{Correspondence}

\section{Gde Rurus Suryawan}

Department of Cardiology and Vascular Medicine, Soetomo General Hospital,

Airlangga University, Mayjend. Prof.

Dr. Moestopo Street No.6-8, Surabaya, INDONESIA

E-mail: igde.rurus.s@fk.unair.ac.id History

- Submission Date: 23-1-2020;

- Review completed: 02-02-2020;

- Accepted Date: 11-02-2020.

DOI : 10.5530/pj.2020.12.66

Article Available online

http://www.phcogj.com/v12/i3

\section{Copyright}

(C) 2020 Phcogi.Com. This is an openaccess article distributed under the term of the Creative Commons Attribution 4.0 International license.

\begin{abstract}
Adipose-derived Mesenchymal Stem Cells (AMSCs) have promising ability to differentiate into a cardiomyocyte. However, post-transplantation survival of AMSCs is relatively low due to lethal cellular hypoxia. Hypoxic preconditioning is a sublethal hypoxia condition which may improve AMSCs survival. This research evaluates the effect of hypoxic preconditioning on the expression of reactive oxygen species (ROS) and superoxide dismutase (SOD) of AMSCs. Isolated human AMSCs was cultured to the $4^{\text {th }}$ passage and confirmed with CD45, CD90 and CD105 expression. Cells were divided into control group (normoxia with $21 \% \mathrm{O}_{2}$ ) and hypoxic preconditioning group (with $1 \% \mathrm{O}_{2}$ ). ROS and SOD were evaluated using immunofluorescence and analyzed using SPSS 25. AMSCs was characterized by the CD105 and CD90 without expression of CD44 and CD45. ROS expression is significantly lower in hypoxia group than in controlled group $(253,13 \pm 67,795$ vs $342,13 \pm 116,447 ; p<0.05)$ and SOD expression is significantly higher in hypoxia group than in controlled group $(340,25 \pm 96,476$ vs 234,56 $\pm 38,238 ; \mathrm{p}<0.05)$. In conclusion, hypoxic preconditioning in human AMSCs induce lower expression of intracellular ROS and higher expression of intracellular SOD.

Key words: Antioxidant, Hypoxia, Oxidative Stress, Stem Cells.
\end{abstract}

\section{INTRODUCTION}

Cardiovascular diseases are the leading cause of mortality and morbidity worldwide, especially in the developing country. ${ }^{1-3}$ Coronary Heart Disease incidence in the low-income country is twice compared to the high-income country, approximately 10.1 per 1000 person per year in the low-income country and 5.2 per 1000 person-year in the high-income country. ${ }^{2}$ It is estimated that half of the global cardiovascular burden is happened in Asia, mostly from South East Asia countries. ${ }^{4,5}$ On the other hand, the mortality rate of coronary heart disease in the high-income country is predicted continuing declined from 34,4\% from 2005 into $27 \%$ by $2030 .^{2}$ Differences in medical management are considered to be the cause of higher mortality in the low-income country.

Coronary artery disease is the major cause of increased heart failure prevalence. ${ }^{2,3,6}$ Heart Failure prevalence is continued to rise over time from 5,7 in 2009 into 6,5 in $2019 .{ }^{2}$ Despite the fact that current management of coronary artery disease with angioplasty and thrombolytic agents may able to revascularize the area of infarction, these treatments cannot replace scarred cardiac tissues with impaired functional contractility. ${ }^{3}$ Cardiac transplantation is the preferred treatment for endstage heart failure; however, only a few donors are available and there are many ethical debates.

Mesenchymal stem cells (MSCs) has been proven able to regenerate cardiomyocyte and easier to be harvested from autologous source. ${ }^{7-9}$ MSCs have pro-angiogenic potential, antiapoptotic effect, and homing capabilities which contributes toward cell regeneration. ${ }^{8,10}$ However, regeneration using MSCs usually have low cell retention and survival. Hence, several techniques are developed to prevent low cell retention, such as the usage of pharmacological agents, trophic factor, and physical factors. ${ }^{3,8}$

Mesenchymal Stem Cells isolated from unhealthy individuals have an impaired self-renewal ability which is caused by the imbalance of Reactive Oxygen Species (ROS) and antioxidant availabilities inside MSCs. ${ }^{11-14}$ Hypoxic preconditioning (HPC), a sublethal hypoxic state that can stimulate the endogenous mechanism of MSCs, is responded to by several cellular processes such as protein expression that can protect these cells from lethal hypoxia and other ischemic conditions. Hypoxic preconditioning was shown to increase stem cell viability and angiogenesis, thus decrease cell damage and apoptosis. ${ }^{15,16}$ It is suggested that hypoxic preconditioning with $1 \%$ Oxygen may inhibit cell apoptosis via increasing the secretion of angiogenic factors, VEGF, and basic fibroblast growth factor. ${ }^{17}$ Hypoxic preconditioning may also alter the antioxidant balance inside AMSCs which may also affect its survival. Hence, in this research, we evaluated the effect of hypoxic preconditioning on the ROS and superoxide dismutase (SOD) level of the AMSCs.

\section{MATERIALS AND METHODS}

\section{Materials}

Human adipose-derived MSCs obtained from a healthy donor and isolated in Stem Cell Research and Development Laboratory, Airlangga University. a-MEM Medium (STEMCell Technologies, Canada), Collagenase (Thermo Fisher Scientific, USA), Fetal

Cite this article: Suryawan IGR, Andrianto, Cahyaningtias RD, Al-Farabi MJ. Hypoxic Preconditioning Decrease ROS and Increase SOD expression in Adipose-Derived Mesenchymal Cell. Pharmacog J. 2020;12(3):430-5. 
Bovine Serum (Sigma-Aldrich, USA). Mouse anti-human CD90, CD105 and CD45 monoclonal antibody (Abcam, UK), alexa Fluor 488 labelled-secondary goat anti-mouse antibody (Abcam, UK), Cyflow Cube 8 kit (Partec, Germany), formaldehyde (Sigma-Aldrich, USA).

\section{Methods}

\section{Experimental design and research procedure}

This true experimental research use post-test control group design which compares the ROS and SOD level of AMSCs in hypoxic group $\left(\mathrm{O}_{2}\right.$ $1 \%)$ with normoxia group $\left(\mathrm{O}_{2} 21 \%\right)$. AMSCs was obtained from healthy volunteer which has been screened for any acute and chronic diseases. Donor has signed written informed consent and all information about personal details are omitted. All research protocol has been approved by Soetomo General Hospital local ethics committee.

\section{Cell culture}

Briefly, adipose tissues were extracted with local anaesthesia and collected in the tube. Adipose tissue then mixed with buffer, collagenase solution and $1 \%$ antibiotic solution then washed to twice to remove blood vessel and connective tissue. Adipose then digested with $5 \mathrm{ml}$ fetal bovine serum until only $5 \%$ remained, separated and platted into 8 well plates. Cells then mixed with $\alpha$-MEM and grown in a humidified incubator with $5 \% \mathrm{CO}_{2}$ at the temperature of $37^{\circ} \mathrm{C}$.

\section{AMSCs characterization}

To examine the expression of CD90+, CD105+ CD45- under normoxic or hypoxic culture for $12 \mathrm{~h}$ at $37^{\circ} \mathrm{C}$, cells were harvested and stained with anti-CD90 and anti CD45 and evaluated using a Cyflow Cube 8 kit. Indirect immunofluorescence was used to evaluate CD90, CD105 and CD45 expression.

\section{Hypoxic preconditioning}

AMSCs were divided into hypoxic preconditioning group with $\mathrm{O}_{2} 1 \%$ in 24 hours and normoxia group with $\mathrm{O}_{2} 21 \%$ in 24 hours. AMSCs then fixed in object-glass with $10 \%$ formaldehyde.

\section{Immunofluorescence}

ROS and SOD level was evaluated using immunofluorescence. Briefly, AMSCs were prepared in $5 \times 10^{5}$ concentrations in $1 \mathrm{~mL}$ of culture media. $100 \mu \mathrm{L}$ of cell suspension was added onto each well of a 96-well plate and incubated overnight in $37{ }^{\circ} \mathrm{C}, 5 \% \mathrm{CO}_{2}$. Subsequently, $50 \mu \mathrm{L}$ of $10 \%$ buffered formalin solution was added onto the cell layer and incubated for $20 \mathrm{~min}$. Primary antibody solutions were added directly after the aspiration of the blocking solution. After $30 \mathrm{~min}$ or $1 \mathrm{~h}$ of incubation, the primary antibody was removed, the wells were washed three times with PBS, and secondary goat anti-mouse (Alexa Fluor 488) was added and incubated for $40 \mathrm{~min}$. In order to obtain double staining, the secondary antibody was removed. Immunofluorescence staining was analyzed using an Olympus IX51 fluorescence microscope and images were obtained using an Olympus DP21 camera.

\section{Statistical analysis}

Statistical analyses were performed using IBM SPSS Statistics 25.0 (IBM Corp, USA). Data were considered to be significantly different if $\mathrm{p}<0.05$. Data, presented as mean $\pm \mathrm{SD}$, were evaluated for normal distribution and compared using an appropriate test.

\section{RESULTS}

\section{AMSCs characterization and quantification}

AMSCs was obtained from a healthy volunteer. The cultured cell was confirmed to express CD105, CD90 but no expression of CD45. Suggesting that the cultured cell is characterized as AMSCs (Figure 1).

Identification of AMSCs was based The International Society for Cellular Therapy guideline, which showed that AMSCs should express CD105, CD90, dan CD73 and not expressing CD45, CD34, CD14, CD11b, CD79, CD19 and HLA-DR. In this research, AMSCs quantification using flowcytometry analysis showed that the cultured cell predominantly express CD90 with very low expression of CD45 (Figure 2).

\section{The effect of hypoxic preconditioning on ROS and SOD expression}

Qualitatively, it can be seen that SOD expression was higher on the AMSCs on the hypoxic group $\left(\mathrm{O}_{2} 1 \%\right)$ while ROS is higher normoxia oxygen $\left(\mathrm{O}_{2} 21 \%\right)$ (Figure 3).

Based on statistical analysis using the T-test, it was found that AMSCs under hypondic preconditioning had lower ROS expression compared to the normoxia group ( $\mathrm{p}<0.001$ ) (Figure 4). whereas AMSCs under the hypoxic precondition group had higher SOD expression compared to the normoxia group $(\mathrm{p}<0.001)$ (Figure 5).

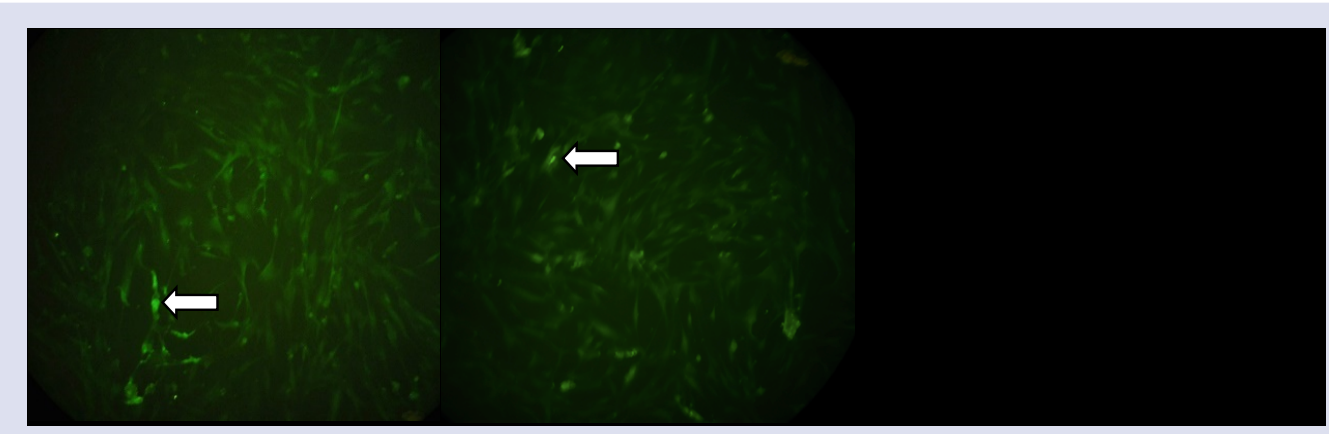

Figure 1: Characterization of AMSCs under 100x magnification (a) AMSCs showed positive expression of CD105 (white arrow); (b) AMSCs showed positive expression of CD90 (white arrow); (c) AMSCs showed no expression of CD45. White bar represents $100 \mu \mathrm{m}$. 

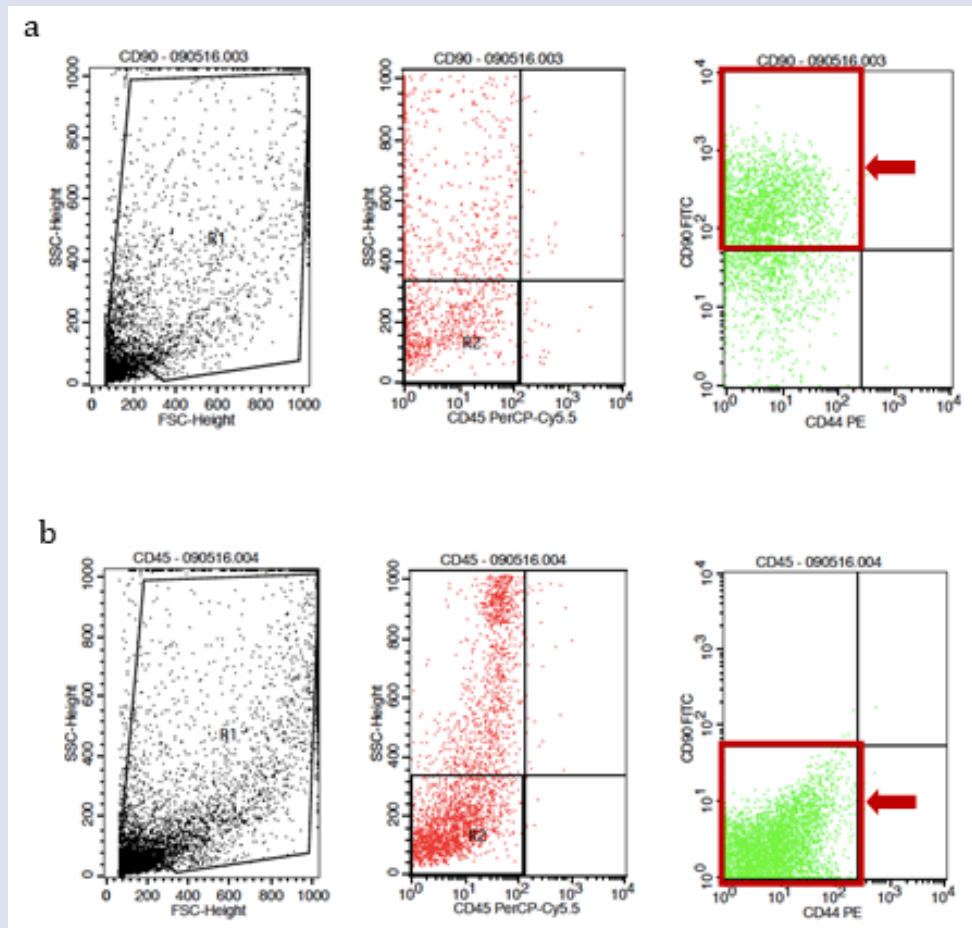

Figure 2: AMSCs characterization using Anti-CD44, Anti-CD45 and Anti-CD90 through flowcytometry analysis. (a) Upper Left region showed cells were predominantly express C90; (b) Lower left region showed cells were predominantly did not express of CD45.

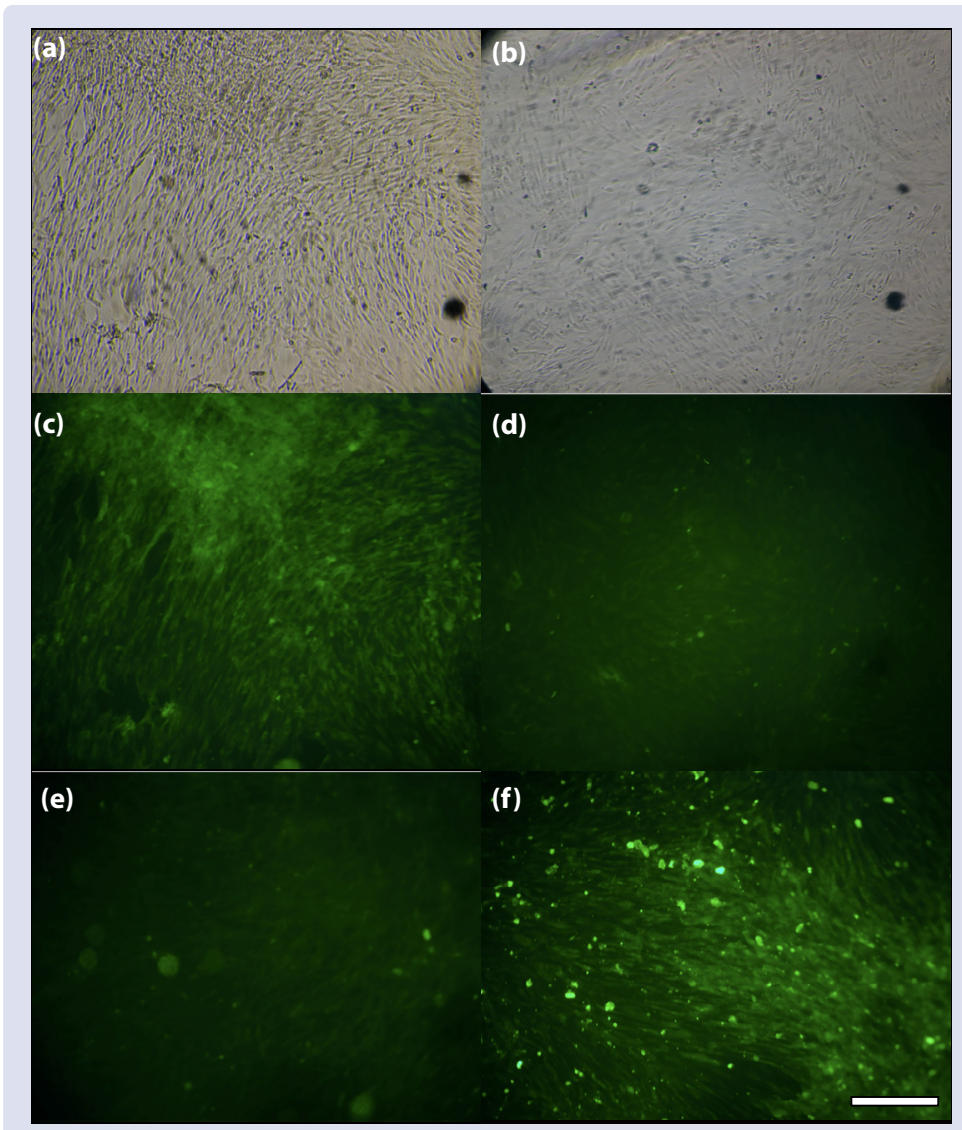

Figure 3: AMSCs under 100x magnification with an inverted microscope for (a) Normoxia group (b) Hypoxic group. ROS expression under 100x magnification with a fluorescence microscope for (c) Normoxia group (d) Hypoxic group. SOD expression under 100x magnification with a fluorescence microscope for (e) Normoxia group (f) Hypoxic group. White bar represents $100 \mu \mathrm{m}$. 


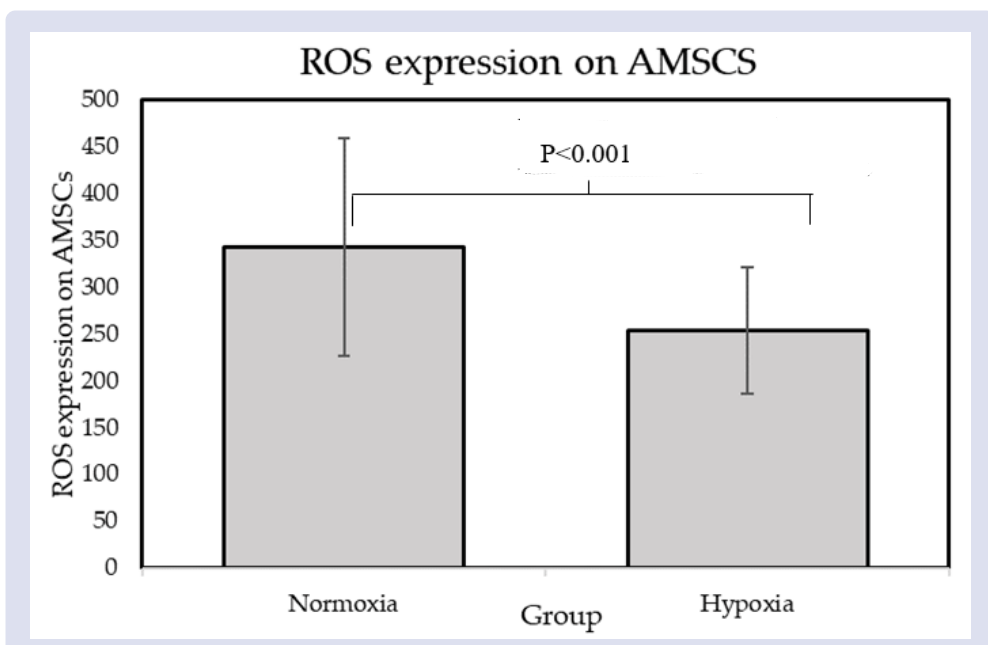

Figure 4: ROS expression on AMSCs treated with (a) Normoxia condition $\left(21 \% \mathrm{O}_{2}\right)$ and (b) Hypoxic precondition $\left(1 \% \mathrm{O}_{2}\right)$.

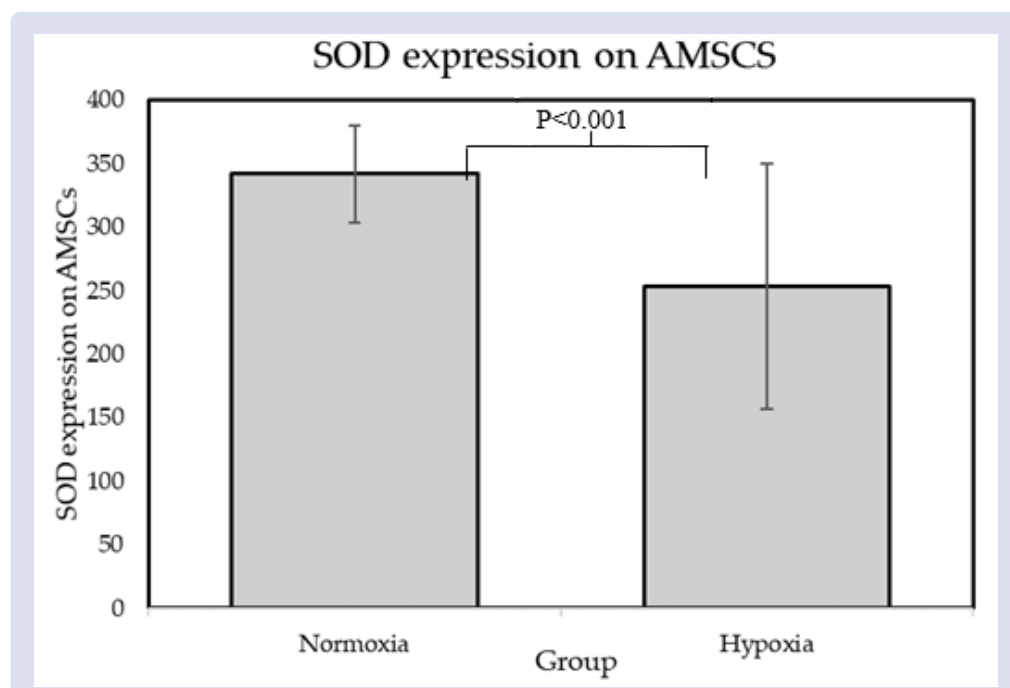

Figure 5: SOD expression on AMSCs treated with (a) Normoxia condition $\left(21 \% \mathrm{O}_{2}\right)$ and (b) Hypoxic precondition $\left(1 \% \mathrm{O}_{2}\right)$.

\section{DISCUSSION}

Overexpression of ROS in the stem cells might impair cellular proliferation, self-renewal and differentiation of MSCs. Hypoxic preconditioning has been proven to have a protective effect against necrosis in in-vitro models of ischemia/reperfusion. ${ }^{18}$ In this research, we have confirmed that hypoxic preconditioning is protective against oxidative stress in the AMSCs. Hypoxic preconditioning on AMSCs with $1 \% \mathrm{O}_{2}$ level express significantly lower ROS level compared to normoxia group. The similar result was observed on the dental pulp cell which showed hypoxic preconditioning is able to decrease ROS level significantly. ${ }^{19}$ Another research also showed that hypoxic preconditioning on chicken cardiomyocyte reduces ROS produced by mitochondria site III electron transport inhibitor mytxothiazol. ${ }^{20}$ Other oxidative stress product such as $\mathrm{H}_{2} \mathrm{O}_{2}$ also decreased in the cortical neuronal cell with hypoxic preconditioning environment. ${ }^{21,22}$ Hence, it is suggested that hypoxic preconditioning may improve AMSCs tolerance toward oxidative stress after transplantation. While the exact mechanism of the lower ROS level in the hypoxic preconditioning groups is not explored in this research, it is suggested that this effect may involve an increased level of glycolytic metabolism which reduce tricarboxylic acid cycle and oxidative phosphorylation, hence reducing mitochondrial ROS production. ${ }^{23}$
Another possible mechanism of the ROS reduction in AMSCs is the increasing levels of antioxidant enzymes. In this research, we found that AMSCs in the hypoxic preconditioning group have higher SOD expression compared to normoxia group. Similarly, hypoxic preconditioning in the cortical neuron increased $\mathrm{Cu} / \mathrm{Zn}$ SOD and Mn-SOD level. ${ }^{21}$ In the in vivo model, hypoxic preconditioning has been proven to increase intracellular SOD level in the lung and kidney of rat. ${ }^{24,25}$ SOD has been proven to be protective against ischemia and reperfusion injury through ROS reduction in transgenic mice. ${ }^{26}$ This suggests that higher SOD expression in the hypoxic preconditioning group may be involved in the ROS reduction in the AMSCs. SOD enables the conversion of ROS to $\mathrm{O}_{2}$ and $\mathrm{H}_{2} \mathrm{O}_{2}$ through sequential oxidation-reduction of metalloproteins of the enzyme catalytic sites, thus counteract the excessive accumulation of ROS in the stem cells. ${ }^{27}$

While this research proves the beneficial effect of hypoxic preconditioning on the AMSCs, this research did not evaluate the time-dependent effect of hypoxic preconditioning on the ROS and SOD expression of the AMSCs. Further research should be directed to evaluate the trend of ROS and SOD changes after hypoxic preconditioning and physiological changes which may occur. 


\section{CONCLUSIONS}

Hypoxic preconditioning of AMSCs with $1 \% \mathrm{O}_{2}$ increases intracellular SOD level and decrease ROS, which may benefit AMSCs survival and proliferation capability after being transplanted.

\section{SUPPLEMENTARY MATERIALS}

\section{Author contributions}

Conceptualization, I.G.R.S., R.D.C and A.; methodology, R.D.C., M.J.A.; software, I.G.R.S. and M.J.A.; validation, I.G.R.S. and A...; formal analysis, M.J.A.; investigation, M.J.A, R.D.C, A.; resources, I.G.R.S. and A.; data curation, R.D.C and M.J.A.; writing-original draft preparation, M.J.A.; writing-review and editing, I.G.R.S.; visualization, M.J.A.; supervision, A.; project administration, R.D.C and M.J.A.; funding acquisition, I.G.R.S.

\section{Funding}

This research received no external funding

\section{Conflicts of interest}

The authors declare no conflicts of interest.

\section{REFERENCES}

1. Rosengren A, Smyth A, Rangarajan S, Ramasundarahettige C, Bangdiwala SI, AlHabib KF, et al. Socioeconomic status and risk of cardiovascular disease in 20 low-income, middle-income, and high-income countries: the Prospective Urban Rural Epidemiologic (PURE) study. Lancet Glob Heal. 2019;1-13.

2. Benjamin EJ, Virani SS, Callaway CW, Chamberlain AM, Chang AR, Cheng $\mathrm{S}$, et al. Heart disease and stroke statistics - 2018 update: A report from the American Heart Association. Circulation. 2018;137:67-492.

3. Kishore R, Tang $Y L$, Zhang J, Sun $T$, Chen L, Cheng M, et al. Hypoxic Preconditioning Enhances the Benefit of Cardiac Progenitor Cell Therapy for Treatment of Myocardial Infarction by Inducing CXCR4 Expression. Circulation Research. 2009;134:1209-16.

4. Ohira T, Iso H. Cardiovascular disease epidemiology in Asia: an overview. Circ J. 2013;77(7):1646-52.

5. Lam CSP. Heart failure in Southeast Asia: facts and numbers. ESC Hear Fail. 2015;2(2):46-9

6. Reyes EB, Ha JW, Firdaus I, Ghazi AM, Phrommintikul A, Sim D, et al. Heart failure across Asia: Same healthcare burden but differences in organization of care. International Journal of Cardiology. 2016;223:163-7.

7. Ho SS, Hung BP, Heyrani N, Lee MA, Leach JK. Hypoxic Preconditioning of Mesenchymal Stem Cells with Subsequent Spheroid Formation Accelerates Repair of Segmental Bone Defects. Stem Cells. 2018;36(9):1393-403.

8. $\mathrm{Hu} \mathrm{C}, \mathrm{Li}$ L. Preconditioning influences mesenchymal stem cell properties in vitro and in vivo. J Cell Mol Med. 2018;22(3):1428-42.

9. Tian XQ, Yang YJ, Li Q, Huang P Sen, Li XD, Jin C, et al. Globular adiponectin inhibits the apoptosis of mesenchymal stem cells induced by hypoxia and serum deprivation via the AdipoR1-mediated pathway. Cell Physiol Biochem. 2016;38(3):909-25.
10. Williams AR, Hare JM. Mesenchymal stem cells: Biology, pathophysiology, translational findings, and therapeutic implications for cardiac disease. Circ Res. 2011;109(8):923-40.

11. Barros S De, Dehez S, Arnaud E, Barreau C, Cazavet A, Perez G, et al. Agingrelated Decrease of Human ASC Angiogenic Potential Is Reversed by Hypoxia Preconditioning Through ROS Production. 2013;21(2):399-408.

12. Song L, Yang Y, Dong Q, Qian H, Gao R, Qiao S, et al. Atorvastatin Enhance Efficacy of Mesenchymal Stem Cells Treatment for Swine Myocardial Infarction via Activation of Nitric Oxide Synthase. 2013;8(5):1-12.

13. RobeyTE, Saiget MK, Reinecke H, Murry CE. Systems approaches to preventing transplanted cell death in cardiac repair. J Mol Cell Cardiol. 2008;45(4):567-81.

14. Majzunova M, Dovinova I, Barancik M, Chan JYH. Redox signaling in pathophysiology of hypertension. J Biomed Sci. 2013;18(20):69.

15. Hsiao ST, Lokmic Z, Peshavariya H, Abberton KM, Dusting GJ, Lim SY, et al Hypoxic Conditioning Enhances the Angiogenic Paracrine Activity of Human Adipose-Derived Stem Cells. Stem Cells Dev. 2013;22(10):1614-23.

16. Hadjipanayi E, Schilling AF. Hypoxia-based strategies for angiogenic induction: The dawn of a new era for ischemia therapy and tissue regeneration. Organogenesis. 2013;9(4):261-72.

17. Liu L, Gao J, Yuan Y, Chang Q, Liao Y, Lu F. Hypoxia preconditioned human adipose derived mesenchymal stem cells enhance angiogenic potential via secretion of increased VEGF and bFGF. Cell Biol Int. 2013;37(6):551-60.

18. Grabb MC, Choi DW. Ischemic tolerance in murine cortical cell culture: Critical role for NMDA receptors. J Neurosci. 1999;19(5):1657-62.

19. Liu F, Huang X, Luo Z, He J, Haider F, Song C, et al. Hypoxia-activated PI3K/Akt inhibits oxidative stress via the regulation of reactive oxygen species in human dental pulp cells. Oxid Med Cell Longev. 2019;2019.

20. Vanden Hoek TL, Becker LB, Shao Z, Li C, Schumacker PT. Reactive oxygen species released from mitochondria during brief hypoxia induce preconditioning in cardiomyocytes. J Biol Chem. 1998;273(29):18092-8.

21. Arthur PG, Lim SCC, Meloni BP, Munns SE, Chan A, Knuckey NW. The protective effect of hypoxic preconditioning on cortical neuronal cultures is associated with increases in the activity of several antioxidant enzymes. Brain Res. 2004;1017(1-2):146-54

22. Liu J, Narasimhan P,Yu F, Chan PH. Neuroprotection by hypoxic preconditioning involves oxidative stress-mediated expression of hypoxia-inducible factor and erythropoietin. Stroke. 2005;36(6):1264-9.

23. Vieira HLA, Alves PM, Vercelli A. Modulation of neuronal stem cell differentiation by hypoxia and reactive oxygen species. Prog Neurobiol. 2011;93(3):444-55.

24. Chou T-F, Ma M-C, Tsai C-P, Chen C-F. Enhancement of superoxide dismutase activity in rat lungs after hypoxic preconditioning. Chin J Physiol. 2009;52(5):37683.

25. Chen CF, Tsai SY, Ma MC, Wu MS. Hypoxic preconditioning enhances renal superoxide dismutase levels in rats. J Physiol. 2003;552(2):561-9.

26. Deshmukh DR, Mirochnitchenko O, Ghole VS, Agnese D, Shah PC, Reddell $\mathrm{M}$, et al. Intestinal ischemia and reperfusion injury in transgenic mice overexpressing copper-zinc superoxide dismutase. Am J Physiol - Cell Physiol. 1997;273(442-4):1130-5.

27. Abreu IA, Cabelli DE. Superoxide dismutases-a review of the metal-associated mechanistic variations. Biochim Biophys Acta - Proteins Proteomics. 2010;1804(2):263-74. 


\section{GRAPHICAL ABSTRACT}

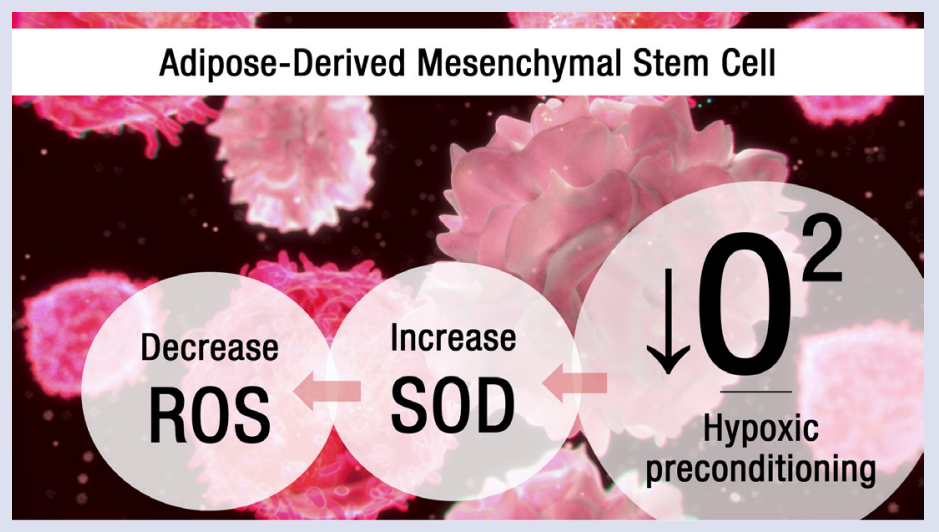

\section{ABOUT AUTHORS}

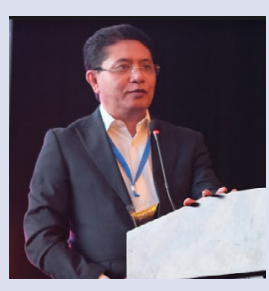

I Gde Rurus Suryawan work as a cardiologist in the Department of Cardiology and Vascular Medicine Soetomo General Hospital and Faculty of Medicine, University of Airlangga. His research interest includes complex interventional cardiology, oxidative stress, adipocyte mesenchymal stem cells, usage of natural compound for cardiac disease and detection of early cardiac markers.
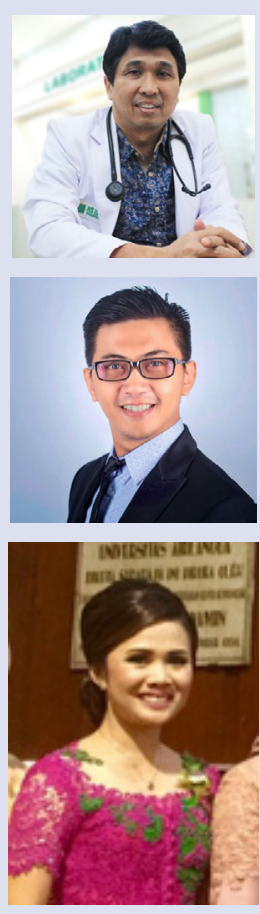

Andrianto is the head of program study for the cardiology residency in the Department of Cardiology and Vascular Medicine Soetomo General Hospital and Faculty of Medicine, University of Airlangga. His research interest includes clinical cardiology, oxidative stress, stem cell dedifferentiation.

Makhyan Jibril Al-Farabi is a cardiology resident in the Department of Cardiology and Vascular Medicine Soetomo General Hospital and Faculty of Medicine, University of Airlangga. He also have postgraduate degree from University College London and Brawijaya University. His research interests includes stem cells, clinical cardiology, cardiometabolic syndrome and Al in cardiology.

Ratna Dewi Cahyaningtias work as cardiologist in Hermina Hospital Sukabbumi. She also graduated from the Department of Cardiology and Vascular Medicine Soetomo General Hospital and Faculty of Medicine, University of Airlangga. Her research interests includes stem cells and clinical cardiology.

Cite this article: Suryawan IGR, Andrianto, Cahyaningtias RD, Al-Farabi MJ. Hypoxic Preconditioning Decrease ROS and Increase SOD expression in Adipose-Derived Mesenchymal Cell. Pharmacog J. 2020;12(3):430-5. 